\title{
Johannes Kepler
}

The German mathematician and astronomer Johannes Kepler is above all famous for discovering the eponymous laws governing planetary motion. Combining Tycho Brahe's meticulous observations and his own theoretical predictions, his astronomical tables were some of the most enduringly accurate ever established. They provided a firm footing for Copernican theory in the face of the then universally acknowledged model of a geocentric universe. Despite poor eyesight that prevented him from carrying out original experimental research, he became a major figure in the field of optics, overhauling all its fundamental concepts and developing a sound mathematical approach that supported Galileo's first telescopic observations.

\section{Riad HAIDAR, haidar@onera.fr}

O ohannes Kepler was born on 27 December 1571 to a family of modest means in the town of Weil der Stadt. His father Heinrich Kepler was a mercenary in the Duke of Württemberg's army. His mother Catherine was the daughter of an innkeeper, and sometimes brewed herbal remedies that earned her the reputation of a healer. Born prematurely, Johannes had a sickly constitution. At the age of 3 years, he contracted smallpox, which almost killed him and left him with very weak eyesight and deformed hands. The Lutheran Protestant Keplers lived a peaceful existence in the Holy Roman Empire, then under the reign of religiously tolerant Maximilian II. In 1576, they moved to Leonberg near Stuttgart, where they opened an inn.

When Johannes was 9 years old, he and his father excitedly witnessed the total lunar eclipse of 31 January 1580, watching the Moon gradually disappear as it passed through the Earth's shadow. This experience made a deep impression on the young boy, and he was to return to it many years later. He was then a pupil of the local Latin school, but in 1583, he entered the Protestant seminary in Adelberg, later graduating to the upper seminary of Maulbronn.

In 1589, his father took up arms once more, never to return. That same year, Johannes became a student at the famous Stift seminary of Tübingen University, founded in 1536. He now seemed firmly set on the path to ordination, although he was not entirely at ease with the Lutheran current of thought set out in the Augsburg Confession of 1530, which then held sway at Tübingen.

At the Stift, he studied philosophy, philology, Greek and above all mathematics, under the supervision of astronomer Michael Maestlin [1550-1631]. As Kepler was both a brilliant and an open-minded student, Maestlin decided to

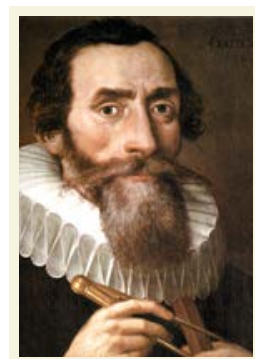

MAIN DATES

Born 27 December 1571, Weil der Stadt (Germany)

1601 Mathematicus imperialis, Prague

1609 First two Kepler laws

1611 Dioptricae publication

1619 The Harmony of the World's third law

A portrait of Johannes Kepler

Deceased 15 November 1630, Regensburg(Germany)

introduce him to the heliocentric theory put forward by Nicolaus Copernicus [1473-1543]. In a world dominated by the Church and the geocentric model devised by Claudius Ptolemy [ca. AD 90 - ca. 168], which placed the Earth at the centre of the universe, this act was nothing short of unlawful. However, his teacher's arguments were so compelling and the reasoning so seductive that Kepler soon became a convinced Copernican. As this new stance was obviously incompatible with the role of a pastor, Kepler abandoned his theology studies and took up a post of mathematics teacher at the Protestant school in Graz in 1594. He also became the official astrologer of Archduke Ferdinand of Habsburg.

\section{Early mathematical research}

Kepler married Barbara Müller on 27 April 1597. It was a love match, arranged by his family. A peasant woman with a forceful personality, Barbara bore him three children and took care of all the household affairs. However, she then contracted Hungarian spotted fever, the couple lost their 6-year-old son Friedrich to smallpox, and she herself died one year later, in 1612.

Kepler rapidly clarified his scientific views, setting down his initial thoughts about planetary motion and how the universe is ordered in Mysterium Cosmographicum. Published in 1596, this work placed him firmly in the avant-garde of astronomy. Brilliant and passionate, and at times movingly naive, it was the first convincing plea for Copernican theory. It also lay the foundations for a whole new science - astrophysics, for unlike his contemporaries, Kepler was also interested in the causes behind the organization of the planets.

In his book, Kepler proposed a model of the solar system based on regular polyhedra. He pictured a soul that attracted inert bodies towards the Sun and induced planetary motion. He even attempted to formulate a mathematical law to describe it, linking the planets' orbital period to their distance from the Sun. This was a splendid intuition, but one based on misconceptions about optics and dynamics, and obviously required more mature reflection. Indeed, it was to take him two decades of thought and effort to fathom out the harmony of the world. 


\section{LE CONNECTEUR USB TYPE-C A DÉBARQUÉ}

His theory of solids put Kepler, then an obscure maths teacher in Graz, in contact with some of his most illustrious contemporaries, including Tycho Brahe [1546-1601], the Danish astronomer responsible for the building of the Uraniborg (literally: Castle of Urania), probably the most important observatory in Europe at that time, and later Galileo Galilei [1564-1642]. Since 1599, Tycho Brahe had held the post of mathematicus imperialis at the court of Rudolf II in Prague. Extremely impressed by the Mysterium Cosmographicum, he invited Kepler to join him. It was an extraordinary opportunity that arose at exactly the right time, for because of his Protestant faith and Copernican ideas, Kepler was facing exile. He duly took refuge in Prague in 1600 , and become assistant mathematician to Tycho Brahe.

For some years, Brahe had been struggling with the inextricable mystery of the Martian orbit. As a result of his work at the Uraniborg, he had precise, reliable and comprehensive astronomical observations to work on, but was unable to make anything of them. Fortunately, while Kepler's eyesight was too poor for him to observe the night skies, he was extraordinarily good with figures. He immediately entered into the spirit of the enterprise, and continued to wrestle with the problem even after Brahe's death in 1601, when he succeeded him as imperial mathematician. This exceptional post, which he occupied until 1612, afforded him privileges he could never have dreamed of as the son of an innkeeper and mercenary.

Understanding the Martian orbit was a massive challenge. According to classical astronomy, which Kepler still espoused (though not for much longer), planets followed a circular orbit, so it should only take a few observations to establish all the parameters. The welter of data amassed by Brahe meant he could easily calculate several sets of parameters and refine them to his heart's content. Working out the orbit should thus have been child's play - a couple of months of routine calculations at the most. The problem was that Mars continued to resist him not just for a few months but for six whole years. The orbit of Mars was not circular - that much was obvious. Like all his contemporaries, Kepler found himself trapped by ancient models and mired in the astronomical certainties of the day, and it took all his powers of inventiveness and intellectual daring to extricate himself. He allowed his imagination free reign, and after much doubt and hesitancy, eventually accepted what his intuition was telling him - that the Red Planet follows an elliptical path around the Sun. Better still, he realized that the line connecting Mars to the Sun sweeps out equal areas in equal times. These areas can therefore be used as a measure of time. By studying the orbits of the other planets in the solar system, he was able to prove the universality of what are now known as the First and Second Laws of Kepler, which he published in Astronomia Nova in 1609. It is impossible to overstate the importance of this discovery. For a start, Isaac Newton [1643-1727] drew on Kepler's law to deductively calculate his Law of Universal Gravitation. Kepler had now entered the pantheon of geniuses of humanity.

\section{La nouvelle caméra uEye LE USB 3.1 Gen 1}
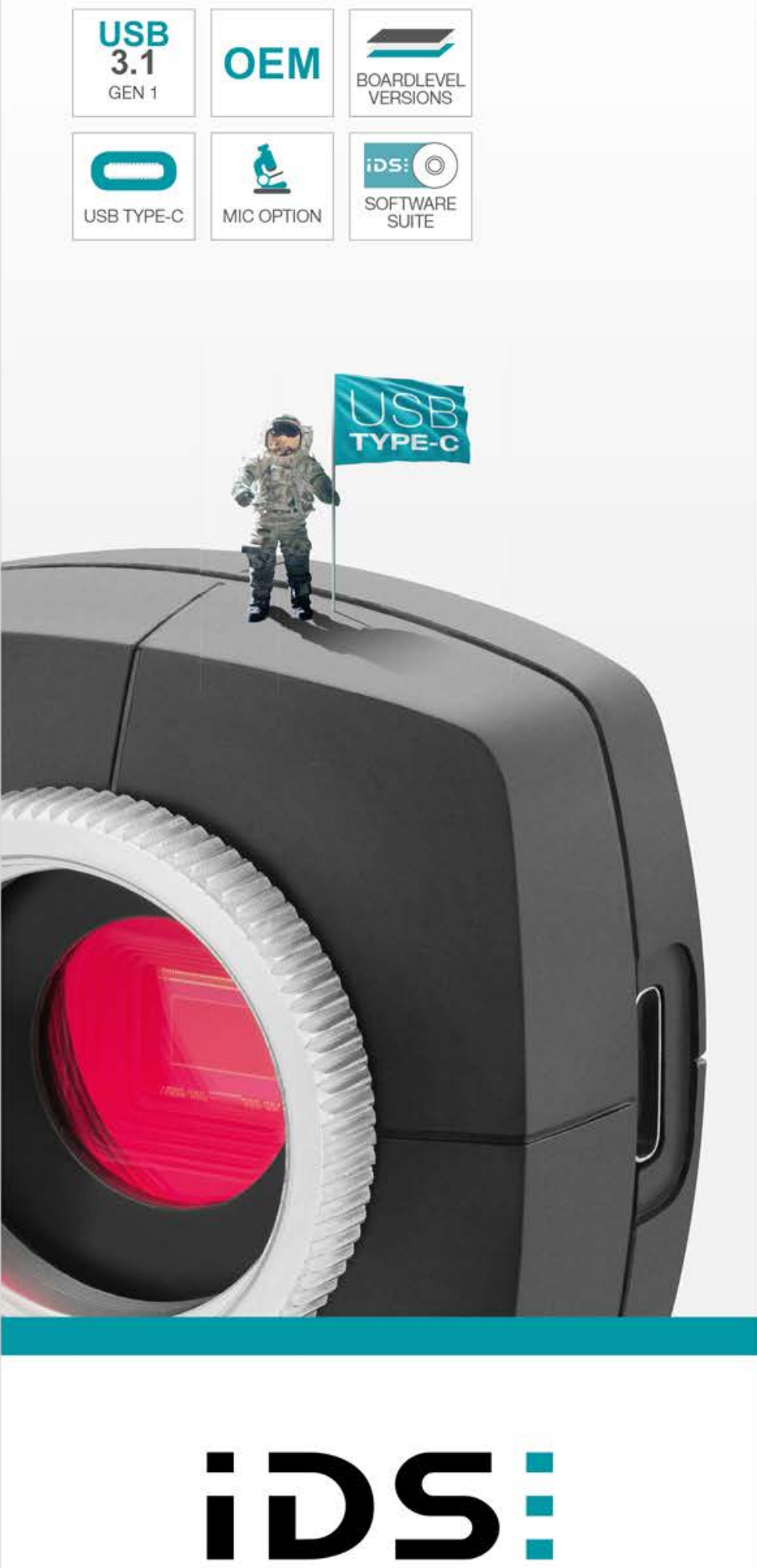

www.ids-imaging.fr/usb3.1 


\section{Optics}

As he tussled with Mars, Kepler become aware of the importance of understanding optical concepts and phenomena if he was to pursue his astronomical research. This was not a culture with which his mentor Maestlin was familiar, and he therefore had to acquire this knowledge on his own, studying the works of the English medieval thinker Roger Bacon [1214-1294] and the Arab scientist Alhazen [965-1039]. In 1604, he published Astronomiae Pars Optica, in which he described the first ever mathematical study of camera obscura and refraction, expressed as the law $I=n \times r$ (small-angle approximation of Snell's law). He was also interested in the mechanism of eyesight, and supported the hypothesis that images are projected onto the retina. His first book about optics was essentially a state of the art, but presented from an astonishingly modern angle with the practical objective of serving Kepler's astronomical research. His second book, Dioptrice, published in 1611, was rather more original. In it, he established his theory of lenses and their combinations, and explained the working of the telescope that Galileo had just used to discovered the satellites of Jupiter.

Kepler enjoyed 10 peaceful and scientifically very productive years in Prague, occupying a comfortable and prestigious position. In 1611, however, the fates dealt him several cruel blows, with the deaths of first his son then his wife, and the abdication of his protector Rudolf II in favour of the latter's brother Matthias. Worse still, his scientific views were viewed with such deep suspicion by the Church that he was excommunicated in 1612. Thus, for a multitude of reasons, the atmosphere in Prague suddenly became oppressive and Kepler was forced to leave the imperial capital, settling in the Austrian town of Linz.

Now a widower, the former imperial mathematician became a very eligible bachelor, and was soon being assiduously courted. His choice fell upon Susanna Reuttinger, the daughter of the hotelier in the neighbouring town of Eferding, who was to bear him seven children. Theirs was a happy marriage, and an amusing anecdote illustrating Kepler's insatiable curiosity is that while he was purchasing the wine for his wedding breakfast, he noticed that the volume of the barrels was estimated by inserting a rod diagonally - an archaic and inaccurate system. He therefore turned his attention to the solids of revolution, calculating their capacity using the method of indivisibles (a precursor of infinitesimal calculus). He published his results in Nova Stereometria Doliorum Vinariorum in 1615.

In the same year, his mother Catherine was accused of witchcraft - a serious charge that could have led to her being burned at the stake. Johannes Kepler intervened, and a lengthy six-year court case ensued. At one point his mother, then aged 70, spent several months behind bars in Güglingen, but she was eventually found not guilty and acquitted in 1621.

\section{The Harmony of the World}

Despite his exile in Linz, Kepler remained first and foremost an astronomer. His work was sustained by the deeply held conviction that the Universe is governed by harmonic laws. This faith in the harmony of the world (Harmonices Mundi was the title of a book published in 1619 in which he assigned a musical theme to each planet) led him to make the troubling, improbable and fantastic discovery of his third law, according to which the square of the orbital period of a planet is directly proportional to the cube of the semimajor axis of its orbit. So intense was this moment of supreme intuition that he recalled the thrill of its discovery in his description of the law.

Calculating astronomical tables was an integral part of an astronomer's or imperial mathematician's work. Kepler had never shirked this chore, despite its tedium. The logarithms invented by John Napier [1550-1617] in 1614 nevertheless came as a great relief both to him and to all his contemporaries, although they remained rather mysterious and their reliability was therefore questioned in some quarters. Kepler was personally convinced of their soundness, and in response to the rampant scepticism of his former mentor Maestlin, he set out to explain how they worked and demonstrate their mathematical relevance in his Chilias Logarithmorum. In the process, he improved on Napier's mode of calculation, using a geometric method to establish a new logarithmic table.

In 1627, Kepler published his magnum opus in Ulm, known as the Rudolphine Tables, a masterful compendium of all his work as a mathematician and astronomer, together with the observations made by Tycho Brahe. Remarkably, given the rapidly developing knowledge of heavenly bodies, these tables remained accurate for several decades - a dazzling confirmation of the accuracy of Kepler's Laws and the relevance of the Copernican model.

\section{Ultima verba}

Kepler died after a short illness on 15 November 1630, at the age of 59. He was buried in the Bavarian town of Regensburg, but in 1632, during the Thirty Years War, the Swedish army destroyed his grave. His manuscripts were discovered in 1773 and retrieved by Catherine II of Russia, and are now kept at the Pulkovo Observatory in Saint Petersburg.

It is hard for us today to imagine the intellectual journeys undertaken by the bold, resolute and politically astute scholars who forged the science we practice today and built the world as we know it. Kepler is one of these scholars, as he revolutionized our vision of the Universe and set us off on a path of discovery that we are still following today, as we revolve relentlessly around the Sun, amidst the stars at the heart of our galaxy.

\section{FURTHER READING}

[1] J.-P. Luminet, L'oeil de Galilée (J.-C. Lattès, 2009). 